\title{
The Financial System of the EU and the Capital Markets Union
}

\author{
Florin Teodor Boldeanu ${ }^{1}$, Ileana Tache ${ }^{2}$
}

\begin{abstract}
:
This paper deals first of all with highlighting the structure of the financial sector in the European Union. It provides a quantitative overview of the role of the different financial and non financial sectors in offering capital funds to accomplish the needs of households, companies, governments, etc.
\end{abstract}

The analysis tries to solve questions such as who provides funds, which uses them, in what forms the finance is formalised or through what channels financial resources flow. The second part analyses some important aspects of the implementation of the Capital Markets Union, which will be a key step in completing the EU Single Market.

Our paper concludes with stating that the integration of the capital markets will be a strong step in supporting economic growth and competitiveness in the EU in the long run.

Key Words: capital markets, financial system, growth, equity markets

${ }^{1}$ Lucian Blaga University of Sibiu, boldeanuflorinteodor@yahoo.com

2 Transilvania University of Brasov, ileanatache@unitbv.ro 


\section{Introduction}

The economic crisis has had a big impact on the financial system in the European Union. Financial risk has to be monitored and supervised more closely.

For the European Central Bank, the market for a given set of financial instruments and/or services is fully integrated if all potential market participants with the same relevant characteristics (1) face a single set of rules when they decide to deal with those financial instruments and/or services; (2) have equal access to the above mentioned set of financial instruments and/or services; and (3) are treated equally when they are active in the market (Baele et al., 2014).

This paper will provide a comprehensive overview regarding the structure of the financial sector in the European Union. The financial system has an important role in financing and stimulating the economy. I will try to highlight the mechanism in which credit is mobilised and answer some key questions like who is providing the funds/credit, where does this credit go to and in which form the credit is formalised or through which channels financial resources flow.

Also, this paper will provide an overview for the development of the Capital Markets Union (CMU). The Capital Markets Union is a plan of the European Commission to create more flexible and more integrated capital markets for the European Union (Abiad, Dell'Ariccia and Li, 2011; Thalassinos, 2014; Thalassinos et al., 2012; 2013; 2014; 2015).

With the CMU, the Commission will explore ways of reducing fragmentation in financial markets, diversifying financing sources, strengthening cross border capital flows and improving access to finance for businesses, particularly SMEs. The investment plan for Europe aims at reversing the drop in investment to fuel the EU's recovery and meeting the long-term needs of the European economy (European Commission, 2015a).

\section{Features of the European financial system}

In the European Union and in the United States there are 15.000 companies that have access to capital markets by issuing either shares or bonds. But there are more companies that finance their activities by other means. These types of companies are approximately 25 million in the EU and about 5.7 million in the United States.

The economy is financed by a variety of sources. For example start-up companies such as family businesses are born by the resources generated at inception and the retained earnings in the future years help them with the needs of capital. Also some advantages offered by suppliers and customers can by consider short term financing. Companies can also be financed by inter company loans, bank loans, government loans, etc. 
In order to understand the financial sector in the European Union, we should map the channels through which financial resources move. It is important to understand who is providing these resources, to whom they are targeted and with which instruments or products.

The financial market in the European Union is bipolar. We have on the one side the Western markets that are all very developed, with many years of tradition and free capital movement and on the other side the Eastern European financial markets that are not so well organized and with not the same capital resources.

In Figure 1 below we can observe the channels through which financial resources move (direct financing through markets, direct financing outside capital markets and intermediation) from the providers of funds to the users of funds.

Figure 1. The flow of financial resources in the economy

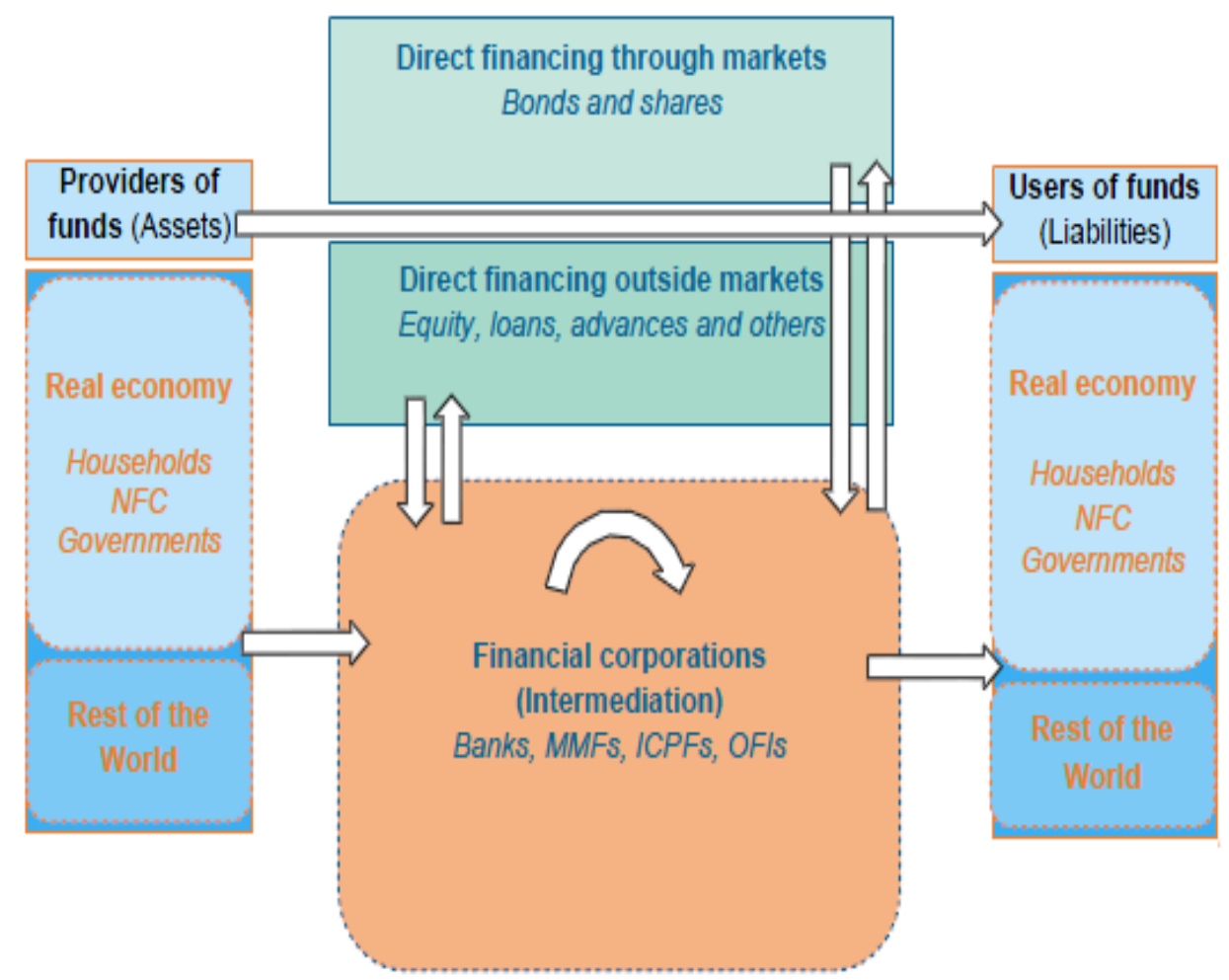

Source: European Financial Stability and Integration Report (EFSIR), April 2015

There are different financial channels through which different entities (households, companies, governments, etc.) can get financial capital to fulfil their investment plans. 
Figure 2. The dimensions of financial relations in an economy

\begin{tabular}{|c|c|c|c|}
\hline $\begin{array}{c}\text { Who? } \\
\text { Institutional sector }\end{array}$ & $\begin{array}{c}\text { What? } \\
\text { Instrument or product }\end{array}$ & $\begin{array}{l}\text { Where? } \\
\text { Geography }\end{array}$ & $\begin{array}{l}\text { How much? } \\
\text { Measurement }\end{array}$ \\
\hline Households & Loans & European Union (EU28) & Absolute terms (Euro) \\
\hline Non-financial corporations (NFCs) & Bonds & euro area (EA18) & Relative terms \\
\hline Governments & Quoted shares & Member States (28) & Percentage of GDP \\
\hline Monetary Financial Institutions (MFls) & Unquoted shares & International comparisons & Percentage of balance sheet \\
\hline Central banks & Deposits & United States & Growth rates \\
\hline Credit institutions & Ins. technical Reserves & Japan & \\
\hline Money Market Funds (MMFs) & Other assets / liabilities & China & \\
\hline Insurance Corporations and Pension Funds (ICPFs) & & Canada & \\
\hline Insurance corporations (ICS) & & G20 & \\
\hline Pension Funds (PFs) & How? & When? & How much? \\
\hline Other Financial Institutions (OFIs) & Circulation of funds & Time & Variable \\
\hline Investment funds (IFs) & Direct financing & Historical perspective & Stocks (outstanding volumes) \\
\hline Financial Vehicle Corporations (FVCs) & Through markets & Annual series & Flows \\
\hline Asset-backed financing & Outside markets & Monthly series & Gross issuances \\
\hline 'Residual' OFls & Financial intermediation & & Redemptions \\
\hline Non-residents (RoW) & & & Net issuances \\
\hline
\end{tabular}

Source: European Financial Stability and Integration Report (EFSIR), April 2015

Figure 2 presents all dimensions of the financial relations in a certain economy. It also highlights all the different actors that help in financing the needs of different entities in an economy.

The total aggregate of the financial balance sheet of the financial sectors in the European Union was about 193.000 billion Euros in the 3rd quarter of 2014. Also the total assets (providers of funds equal $€ 96.500$ billion) are less then total liabilities (users of funds equal $€ 102.300$ billion). Figure 3 shows that households provided more funds than they borrowed.

Governments and non-financial corporations borrowed more funds in the third quarter of 2014. So governments and non-financial companies are net borrowers and this is because they are more risk secure as compared with households that don't have the same capacities to borrow and to offer collaterals in return.

Households account for more than 140\% of GDP in 2014 regarding net savings and their funds ensured the resources needed by the other participants in the economy. 
Figure 3. Aggregate analysis of the size of the institutional sectors in the European Union, in the third quarter of 2014, EU 28, $€$ billion

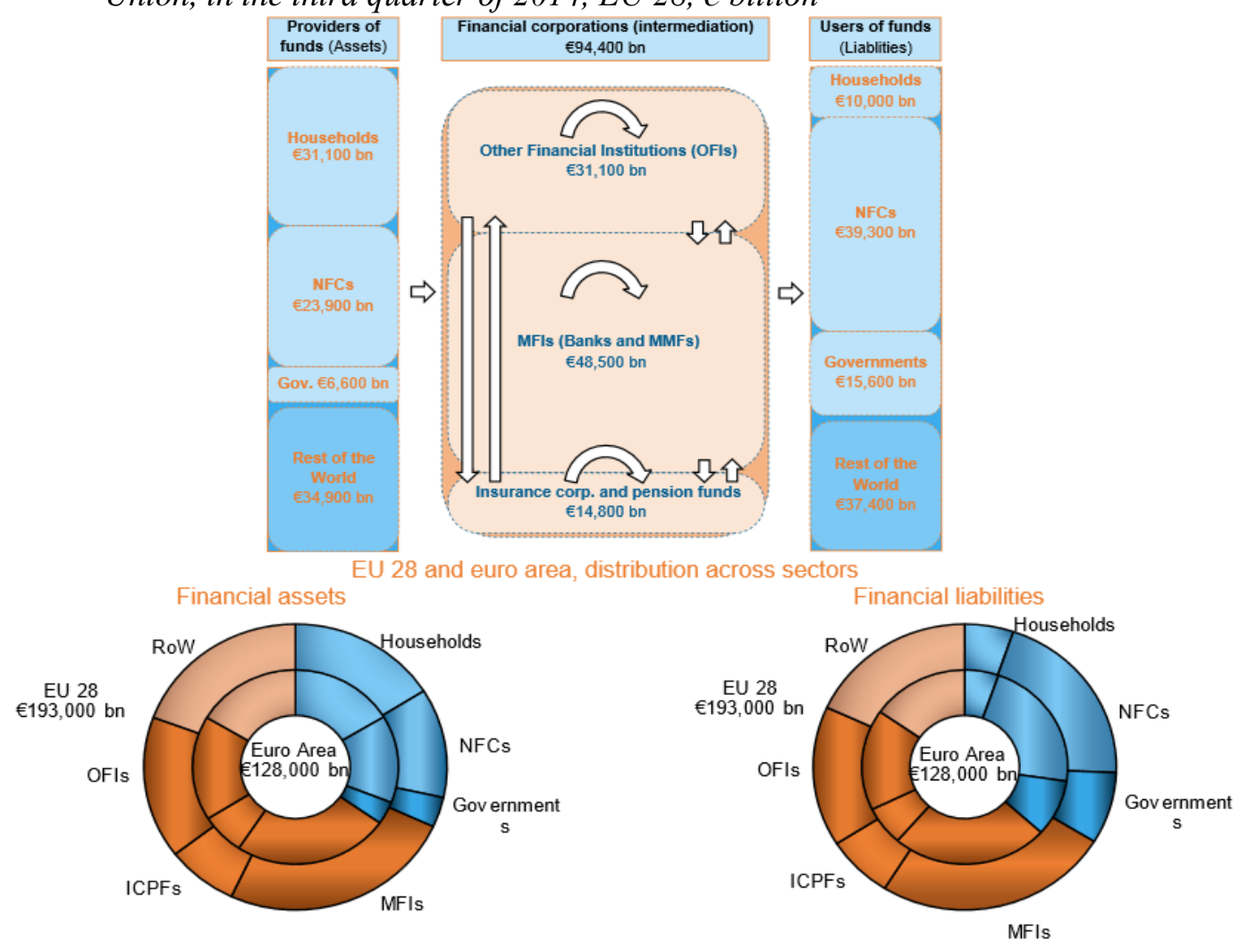

Source: European Financial Stability and Integration Report (EFSIR), April 2015

According to Pagano (2014) and Buttiglione et al. (2014), the size of the financial assets and liabilities in the Euro Area has doubled between 2000 and 2014 as compared with a nominal GDP growth of only $40 \%$. Also the rate debt-to-GDP is still growing since 2005, even if the crisis affected most of the European economies. Deleverage is not done as fast as intended and this affects nominal growth.

\subsection{Country analysis for assets and liabilities}

There are differences in the total size of assets and liabilities in the European Union. In countries like Poland, Romania or Lithuania, the total aggregates are less than $500 \%$ of annual GDP as compared with $30.000 \%$ in Luxembourg. These big differences appear because of the nature and size of the financial sectors in the Western European Countries. Also many international headquarters of different world banks are more or less placed in Western European Countries (European Commission, 2014a). 
Figure 4. Balance sheet of institutional sectors, \% of GDP, Q3 - 2014

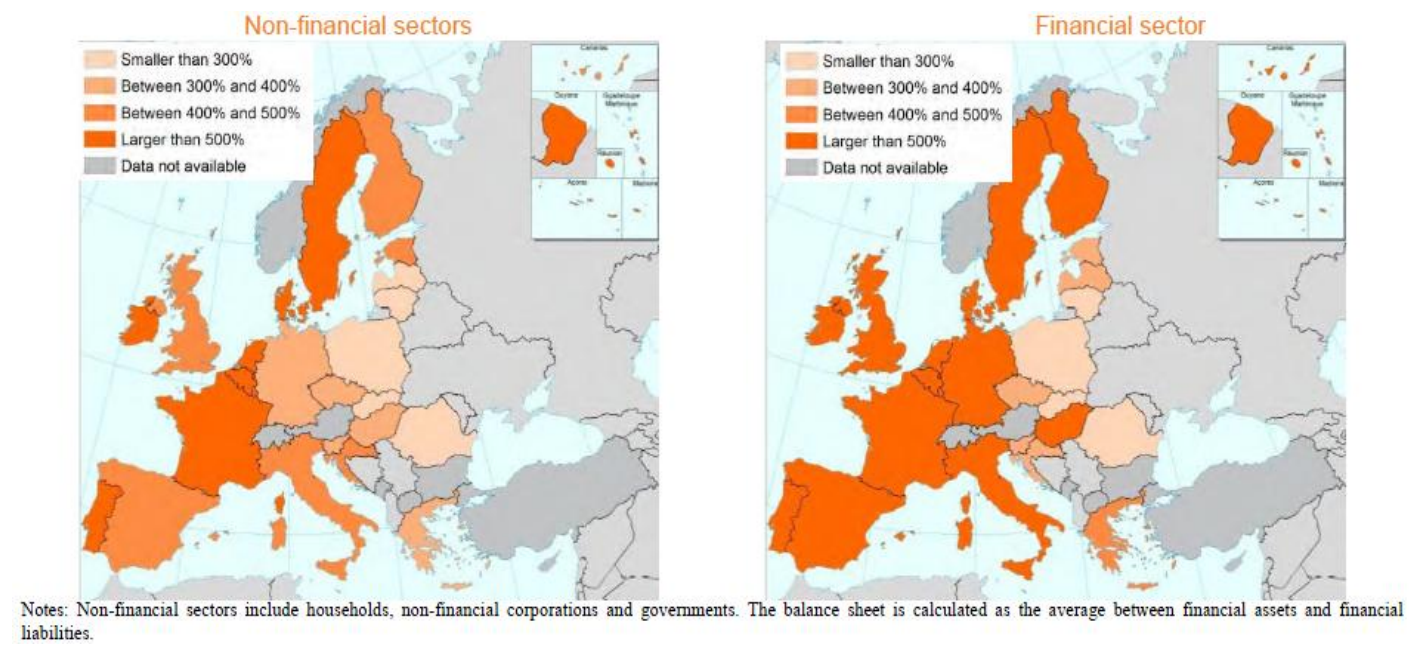

Source: European Financial Stability and Integration Report (EFSIR), April 2015

Regarding net savings and net borrowing in the European Union, there are major differences between sectors (European Commission, 2015b). As mentioned before, households are the ones that provide the most financial resources for the economy in the European Union and non-financial organizations are the main consumers of capital. The Belgians, Britons, Italians and Maltese citizens contribute the most to allocate funds to finance the economy and citizens from Romania, Greece, Poland, Slovakia and Lithuania have the lowest net rates in the EU.

Many governments are net borrowers, with more than 100\% of GDP being borrowed in Greece, Belgium, Italy and Portugal. Also, in the external sector - , the rest of the world" countries are net borrowers for the European Union. The financial sector, even if it has a large aggregate size regarding assets and liabilities, doesn't finance the economy as compared with the households.

\subsection{Products and instruments of funding the economy}

The main instruments of savings for the different types of Euro Area sectors include currency and deposits, bonds, quoted shares, other equity, insurance technical reserves, loans and other assets.

The non-financial sector - (households, non-financial companies, public corporations, etc.) have more than $30 \%$ invested in non-quoted shares and about $24 \%$ in deposits and currency. Insurance technical reserves (pension funds) account for $32 \%$ of the total assets of households, but for non-financial organizations these types of assets are not relevant. NFC's also use inters company loans and $21 \%$ of the assets of governments represent loans for other sectors. 
Figure 5. Financial assets, Euro Area, $€$ billion
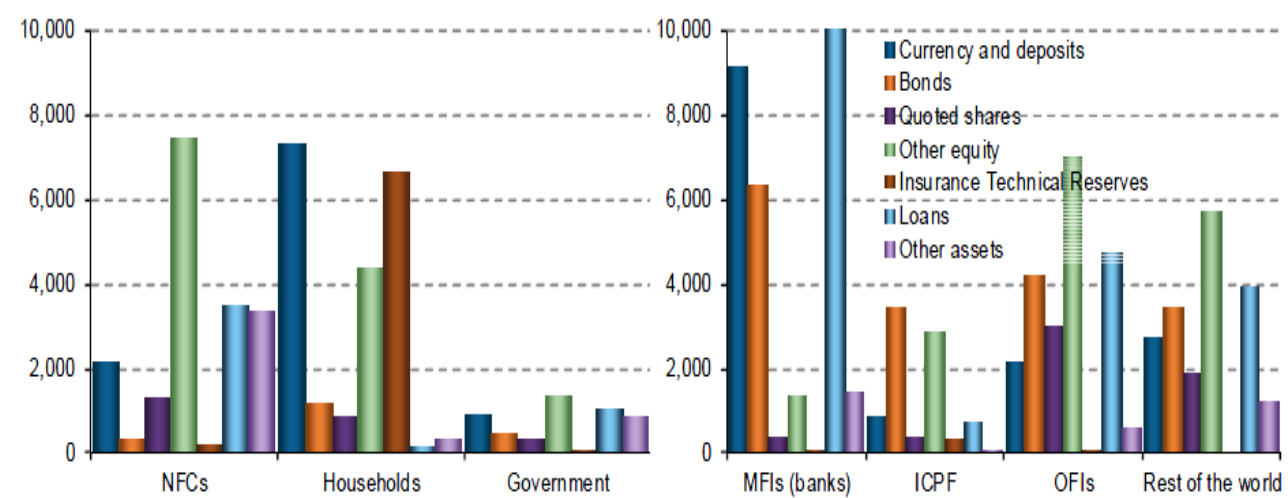

Note: MFIs loans: $€ 12600$ bn. MFIs currency and deposits includes mainly interbank lending provided. NFCs: non-financial corporations, MFIs: monetary and financial institutions, ICPF insurance copporations and pension funds, OFIs: other financial institutions. 'Other equity' includes holdings of investment funds shares, which is particularly significant for ICPF. 'Insurance technical reserves' include pensions and standardized guarantee schemes.

Source: European Financial Stability and Integration Report (EFSIR), April 2015

The financial sector has the main assets represented by loans, currency and deposits, but we must take into account that these assets represent also inter-bank (interfinancial) loans and deposits. Only a part of the assets are used to finance the economy. Also the financial sector has a total of 80.000 billion Euros in financial assets, with the non-banking sector being half of that.

Funds invested in bonds and shares are quite limited as compared with the other assets. Non-financial companies are the ones that invest more in shares, with households investing more in bonds.

Figure 6. Financial liabilities, Euro Area, $€$ billion

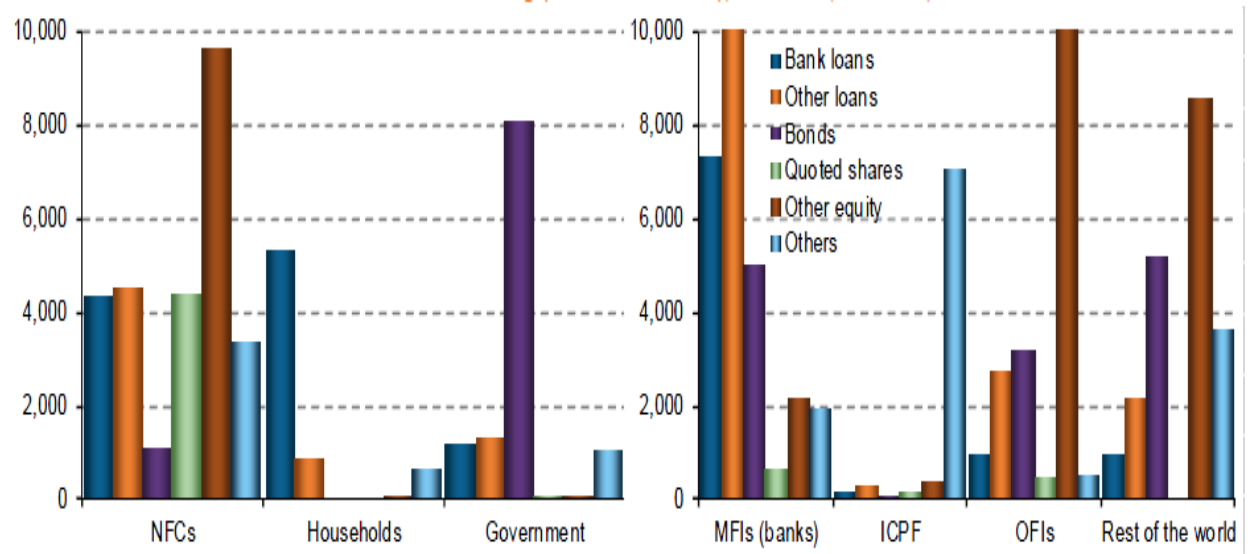

Note: 'Bank loans' for MFIs correspond to interbank deposits received. 'Other loans' for. MFls correspond to deposit received (other than interbank): $€ 14000$ billion. 'Other equity' for OFIs: $€ 12700$ billion. NFCs: non-financial copporations, MFIs: monetary and financial institutions, ICPFs: insurance corporations and pension funds, OFIs: other financial institutions. 'Other financing' for ICPFs corresponds to insurance technical reserves. Invesment fund shares and mutual fund shares are included in other equity.

Source: European Financial Stability and Integration Report (EFSIR), April 2015 
There is a difference between the financial liabilities and financial assets in the European Union, but the sources of the funds that the economy needs is dependent on the forms in which the different sectors choose to save.

Non-financial organizations choose to fund their investments by own capital (51.4\% of their total liabilities). Loans are also very much used by European companies to finance their needs, representing almost $15 \%$ of the total funds. Only $3.2 \%$ of the needs of NFC's are financed through bonds in the capital market. More than $64 \%$ of the financial capital needed by EU companies comes from outside the financial sector.

Households finance their needs mostly using loans (75\%). The government gathers their funds mostly by issuing bonds (70\%), bank and other types of loans representing only $10 \%$.

The financial sector relies on deposits and loans from other sectors and also interbank-lending. Capitalization in the financial sector is very low and banks don't usually finance their needs by issuing stocks. Also $15 \%$ of the funds are generated by issuing bonds.

\section{The Capital Markets Union}

Jean-Claude Juncker stated in 2014 that "to improve the financing of our economy, we should further develop and integrate capital markets. This would cut the cost of raising capital, notably for SMEs, and help reduce our very high dependence on bank funding" (European Commission, 2015c).

The implementation of the Capital Markets Union in the next five years is a goal of the European Commission. It will be a difficult task because only $0.05 \%$ of the EU companies are listed on the markets and most of them still rely heavily on bank loans to get their needed funds. The economic crisis has shown that relying only on loans to finance your major activities is not good if the economy is in turmoil.

As we have mentioned earlier, deleveraging has not speeded up so quickly in the EU and banks have more and more non performing loans. On the short term the Capital Markets Union can help banks deleverage faster.

The European Commission has three major objectives regarding the Capital Markets Union (Anderson et al., 2015):

- Better access to finance for businesses in the European Union, with a focus on small and medium sized companies and investing in major infrastructure projects;

- Diversifying and better access to funds for investors in the European Union and also globally; 
- Improving connectivity between investors in and across the EU Member States and making the capital markets more efficient and effective.

Compared with the United States of America, the EU capital markets are more underdeveloped and falling behind the ones in Asia. Figure 6 shows the capital market in the European Union is half the size of the one in USA. Market capitalization and debt has grown a lot compared with the 90's. In 1992 the EU capitalization was 1.3 trillion euros (22\% of GDP) and in 2013 it is more than 8.4 trillion euros. In the above figure we can see that the capital market percentage of GDP in the EU is the smallest one compared with other courtiers. The one in Switzerland is three times the one in the EU.

Figure 7. Stock market capitalization and debt securities, \% GDP in 2013

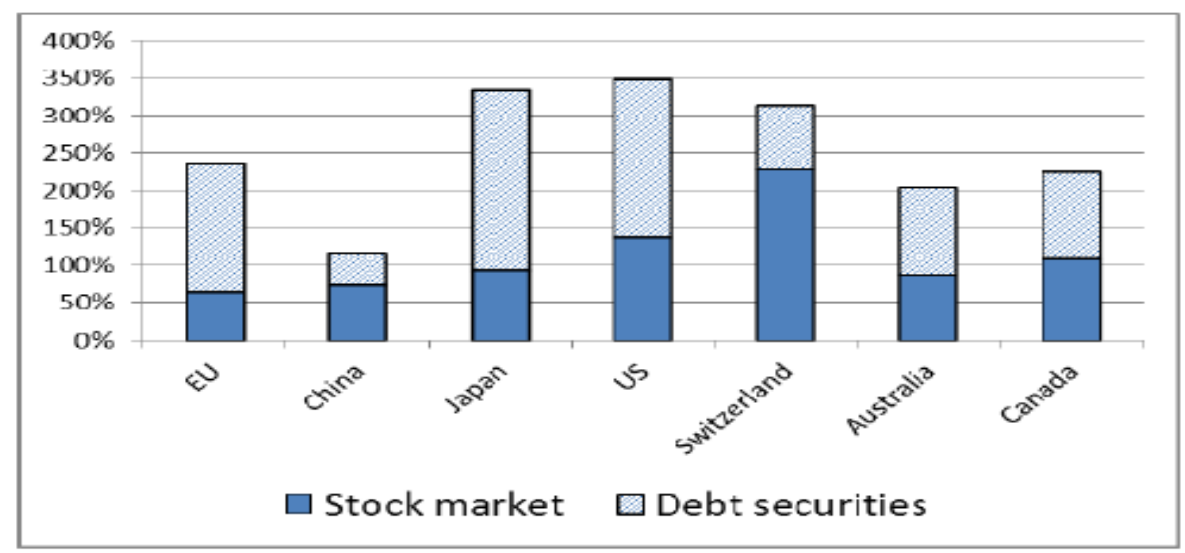

Source: ECMI statistical package

The equity market in the US is twice the size of the one in the European Union, with the bond market being three times larger in America. This poor performance is also due to the fact that the capital market in the Western EU countries is much more developed than the one in the Eastern Europe.

Prior to the 2008 economic crisis, the EU markets started to be more integrated and cross-border acquisitions of financial instruments became much more efficient. But the crisis showed that these investments were mostly based on debt from bank flows and a lot of them were evaporated over night, with people losing their savings.

Most of the equity market is not cross-border linked, but many of the European citizens choose to invest in stocks in their own country. This means that risk and future rewards are not divided between European countries (European Commission, 2015d). 
There are many obstacles in creating a fully integrated capital market. The European Commission (European Commission, 2015e) sees three major challenges in integrating the capital markets in the European Union.

A first challenge is creating an effective market for SMEs so that they can get better finance (new start-ups with high growth and very innovative).

Second of all, EU should improve capital flows for institutional and retail investments. New capital instruments would help in solving this challenge. Also, a growth in private pension provision would facilitate a more diversified European market.

The third challenge is to make the CMU more effective. These will create a much bigger European market. To achieve this plan we should have more competition, a lower the cost of financing, more financial choices and also better distribution of risks. More integration means that the shock absorption of future investments will increase, especially for the equity market.

The European Central Bank is involved in the integration of capital markets in the EU and underlines the importance of the CMU for fostering economic growth (European Central Bank, 2015). The creation of a sustainable and enhanced capital market in the EU will be a long process, but the newly installed European Commission and Parliament are keen in solving this issue in the future medium term.

\section{Conclusions}

The economic crisis has had an effect on the amount of capital flowing in the economy. Households are the back-bone for providing funds to the economy. Banks and NFCs rely on citizen's savings to finance their needs.

Our paper tried in the first part to answer some questions like who provides capital financing for the European economy, where does this credit go to and in what form the credit is formalized or through what channels financial resources flow.

We highlighted some important aspects of the implementation of the Capital Market Union which will be a key step in completing the EU Single Market. The integration of the capital markets will be a strong step in supporting EU's economic growth and competitiveness in the long run. CMU has the potential to complement the Banking Union, strengthen the European Monetary Union (EMU) and foster financial stability. 


\section{References}

Abiad, A., Dell'Ariccia, G., and Li, B. (2011). Creditless Recoveries. IMF Working Paper, No. $11 / 58$.

Anderson, N., Brooke, M., Hume, M., and Kürtösiová, M. (2015). A European Capital Markets Union: implications for growth and stability. Financial Stability Paper 33.

Baele, L. et al. (2014). Measuring financial integration in the euro area. ECB Occasional Paper, No 14.

Buttiglione, L., Lane, P.R., Reichlin, L., and Reinhard, V. (2014). Deleveraging? What Deleveraging? The 16th Geneva Reports on the World Economy. Geneva Reports on the World Economy No.16. International Center for Monetary and Banking Studies and Centre for Economic Policy Research.

European Central Bank (2015). Financial integration in Europe. Frankfurt am Main: European Central Bank.

European Commission (2014a). European Financial Stability and Integration Report (EFSIR), April 2015. Brussels: European Commission.

European Commission (2015a). Commission Staff Working Document. Initial reflections on the obstacles to the development of deep and integrated EU capital markets. SWD (2015) 13.

European Commission (2015b). European Financial Stability and Integration Review. SWD (2015) 98.

European Commission (2015c). Capital markets Union. Brussels: European Commission.

European Commission (2015d). Green paper. Building a Capital Markets Union. SWD (2015) 13 final.

European Commission (2015e). Initial reflections on the obstacles to the development of deep and integrated EU capital markets, accompanying the document Green paper. Building a Capital Markets Union. COM (2015d) 63 final.

Pagano, M. (2014). Is Europe overbanked? Advisory Scientific Committee of the ESRB.

Thalassinos, I.E., Ugurlu, E. and Muratoglu, Y. (2012). Income Inequality and Inflation in the EU. European Research Studies, 15(1), 127.

Thalassinos, I.E, Liapis, K., Rovolis, A. and Galanos, C. (2013). The Clusters of Economic Similarities between EU Countries: A View Under Recent Financial and Debt Crisis. European Research Studies, 16(1), 41.

Thalassinos, E.P. (2014). Credit Default Swaps and Sovereign Debt in Eurozone. Chapter book in Risk Management: Strategies for Economic Development and Challenges in the Financial System,(eds), D. Milos Sprcic, Nova Publishers, 255-278, ISBN: 978163321539-9; 978-163321496-5.

Thalassinos, I.E., Liapis, K. and Thalassinos, E.J. (2014). The role of the rating companies in the recent financial crisis in the Balkan and black sea area. Chapter book in Economic Crisis in Europe and the Balkans, 79-115, Contributions to Economics, Springer International Publishing, DOI: 10.1007/978-3-319-00494-5-6.

Thalassinos, I.E., Th. Stamatopoulos, D.T. and Thalassinos, E.P. (2015). The European Sovereign Debt Crisis and the Role of Credit Swaps. Chapter book in The WSPC Handbook of Futures Markets (eds) W. T. Ziemba and A.G. Malliaris, in memory of Late Milton Miller (Nobel 1990) World Scientific Handbook in Financial Economic Series Vol. 5, Chapter 20. 